NBER WORKING PAPER SERIES

BANK RELATIONSHIPS, BUSINESS CYCLES, AND FINANCIAL CRISES

\author{
Galina Hale \\ Working Paper 17356 \\ http://www.nber.org/papers/w17356 \\ NATIONAL BUREAU OF ECONOMIC RESEARCH \\ 1050 Massachusetts Avenue \\ Cambridge, MA 02138 \\ August 2011
}

I am grateful to Hiro Miura and Chris Candelaria for outstanding research assistance, to Joshua Aizenman for very helpful conversations, to Matthieu Bussiere, Kristin Forbes, Reuven Glick, Charles Engel, Oscar Jorda, Jean Imbs, as well as the participants at a preconference at the NBER Summer Institute 2010, seminars at the Federal Reserve Bank of San Francisco and the Banque de France, and IBEFA session at 2011 AEA meetings for constructive comments and suggestions. I am grateful to Anita Todd for help with preparing the draft. All errors are mine. All views presented in this paper are mine and do not necessarily represent the views of the Federal Reserve Bank of San Francisco, the Federal Reserve Board of Governors, or the National Bureau of Economic Research.

NBER working papers are circulated for discussion and comment purposes. They have not been peerreviewed or been subject to the review by the NBER Board of Directors that accompanies official NBER publications.

(C) 2011 by Galina Hale. All rights reserved. Short sections of text, not to exceed two paragraphs, may be quoted without explicit permission provided that full credit, including $\odot$ notice, is given to the source. 
Bank Relationships, Business Cycles, and Financial Crises

Galina Hale

NBER Working Paper No. 17356

August 2011

JEL No. F34,F36

\begin{abstract}
The importance of information asymmetries in the capital markets is commonly accepted as one of the main reasons for home bias in investment. We posit that effects of such asymmetries may be reduced through relationships between banks established through bank-to-bank lending and provide evidence to support this claim. To analyze dynamics of formation of such relationships during 1980-2009 time period, we construct a global banking network of 7938 banking institutions from 141 countries. We find that recessions and banking crises tend to have negative effects on the formation of new connections and that these effects are not the same for all countries or all banks. We also find that the global financial crisis of 2008-09 had a large negative impact on the formation of new relationships in the global banking network, especially by large banks that have been previously immune to effects of banking crises and recessions.
\end{abstract}

\title{
Galina Hale
}

Economic Research

Federal Reserve Bank of San Francisco

101 Market St., MS 1130

San Francisco, CA 94105

Galina.B.Hale@sf.frb.org

An online appendix is available at:

http://www.nber.org/data-appendix/w17356 


\section{Introduction}

International finance literature has long emphasized the importance of information in international investment, citing information asymmetry as one of the leading explanations for portfolio home bias and lack of international diversification 11 Financial globalization created a number of avenues through which the effects of asymmetric information can potentially be reduced. One of them is international banking in general and lending of banks to each other in particular $2^{2}$ It is commonly accepted that bank lending to corporate borrowers establishes the relationship and produces information flows between the lender and the borrower, which in turn facilitate further lending ${ }^{3}$ It is thus reasonable to believe that lending of one bank to another establishes a channel for information flows between the lender and the borrower that might facilitate future lending, international capital flows of other types, as well as international trade.

Recent global financial crisis had a major impact on the global banking system (Milesi-Ferretti \& Tille, 2011). But did the crisis simply affect the volume of bank lending or did it also affect the structure of international banking system? If relationships between banks play a role, implications of these two developments are not identical. The aim of this paper, therefore, is to investigate the impact of the global financial crisis, as well as of country-specific recessions and banking crises of the past 30 years on the formation of new relationships between banks and the importance of banks in the affected country. To achieve our goal, we use micro-level data on international syndicated bank loans from Loan Analytics database to construct a bank-level global banking network (GBN)

\footnotetext{
${ }^{1} \mathrm{~A}$ number of models of international portfolio flows rely on the assumption of information asymmetry between local and foreign markets (Brennan \& Cao, 1997, Okawa \& Van Wincoop, 2010). Portes et al. (2001) and Portes \& Rey (2005) provide direct evidence of the importance of information in determining bilateral patterns of aggregate international capital flows, while Kang \& Stulz (1997) and Hatchondo (2008) show that such patterns are consistent with the model that is based on asymmetric information. Local informational advantages have also been documented in various contexts in finance literature (Ahearne et al. 2004, Bae et al., 2008, Chan et al., 2008, Coval \& Moscowitz, 2001; Huberman, 2001). Veldcamp \& Van Nieuwerburgh (2009) present a theoretical argument for persistence of information asymmetry.

2 Milesi-Ferretti \& Tille (2011) emphasize prominent growth of international banking prior to the global financial crisis.

${ }^{3}$ See survey by Boot 2000$)$.
} 
and analyze the dynamics of its structure. This is the first study in which bank-level network is analyzed in a global scale $4^{4}$

We construct a global network of banks in which relationships are formed by banks extending loans to each other, taking into account the direction of the lending. Because we are interested in the dynamics of these network statistics, we construct two panel data sets, each at bank-year level. One, noncumulative panel, consists of separate new networks based on loans made in each of the years between 1980 and 2009 thus providing snapshots of lending patterns for each year. The other, cumulative panel is constructed by adding new loans to the network that starts in 1980 and expands through 2009, allowing us to distinguish old and new relationships. For each bank in each year we compute the number of direct lending and borrowing connections, i.e. number of borrowers and lenders, and identify whether the this bank in a given year played a role as a key intermediary, that is whether it was the only bank connecting at least one pair of other banks to each other.

To verify that relationships between banks defined by lending of one bank to another have indeed an effect on lending and borrowing, we demonstrate, in a bank-level fixed effects regression, that establishing a new relationship increases the amount of new loan origination to or by this bank in the following three years. Moreover, in a country-level fixed effects regression, we find that when the number of key banks in a given country increases, that country experiences an increase in both lending and borrowing in at least four years that follow. In a related study, Hale et al. (2011) provide evidence that connections between banks, as defined in this paper, are positively related to international FDI and portfolio flows. Finally, there is evidence that countries in which banks were more connected to other banks through syndicated loan market experienced a lesser impact of the global financial crisis (Caballero et al. 2009).

We next describe the dynamics of the overall network size and connectivity over our sample

${ }^{4}$ In the existing literature, either global network is analyzed at a country level (Garratt et al. 2011. Kubelec \& Sá, 2010; Minoiu \& Reyes, 2011, von Peter, 2007) or bank-level network is constructed for a specific country (Cocco et al., 2009, Craig \& von Peter, 2010). 
period. We find that since the 1980s the global banking network experienced two major periods of rapid expansion — one in the early 1990s and one between 2002 and 2006. These periods of expansion were characterized by an increasing number of banks, increasing number of connections between banks, and increasing number of countries in which banks participate in the GBN. Importantly, network expansion during these periods was achieved more through formation of new connections by existing banks than trough an increase in the number of banks. We also observe that formation of new connections and the share of banks that are key intermediaries tend to decline during recessions in the United States. We very clearly observe a collapse of the GBN during the global financial crisis that brought most measures of the network back to the level that was observed prior to the 2002-2006 expansion.

Before turning to the regression analysis of bank-level network statistics, we present a stylized two-country model of bank relationships that arise endogenously and respond to shocks such as demand, supply, and cost of capital. The model predicts that local recessions in small countries can increase the number of new connections established between the banks initially, but will lower them in the long run. A recession in the United States (a larger country and "the world banker") would increase the number of new connections made because U.S. banks would seek investment abroad. A local systemic banking crisis in a small country, represented by an increase in the cost of funding in this country, would lead to an increase in the number of new relationships formed. A global banking crisis, however, if thought of as a decline in the value of future relationships, would result in fewer new connections.

To study the effects of country-specific recessions and banking crises and to control for the effects of total lending and borrowing when studying the effects of the global financial crisis, we turn to the regression analysis. Because we are interested in the effects on new connections, we conduct our regression analysis using the cumulative network. We find that, conditional on total borrowing and lending, local recessions lead to fewer new connections made by banks in the affected 
country, especially banks that are smaller or that are located in developing countries. We find that local banking crises have a negative effect on the formation of new borrowing connections $5^{5}$ During the recessions in the U.S. large banks are more likely to find new borrowers and establish more new lending connections than during other times. In addition, the number of new key banks tends to fall in countries that experience recessions.

We find a large negative effect of the global financial crisis on the formation of new connections, which was felt most strongly through a decline in entry of new banks from developing countries into the GBN and decline in the number of connections made, especially by large banks ${ }^{6}$ We also find that the formation of new key banks declined and moved from developing to industrial countries during the crisis. These effects of the global financial crisis are conditional on total lending and borrowing as well as on the effects of local recessions that occurred in most countries in our sample during crisis years.

We make the following conclusions from the analysis. Recessions and as banking crises have an important effect on the development of the global banking network through lowering the number of new connections banks make and the distribution of these connections across banks and countries. Thus, we show that in addition to real costs of banking crises (Reinhart \& Rogoff, 2009; Schularick \& Taylor, 2010), there are costs associated with deterioration of bank relationships. Furthermore, we show that the effects of the global financial crisis on the global banking network were especially large and unevenly distributed across banks and countries. Importantly, fewer banks during the crisis played key intermediation roles, especially in developing countries. Combined with the finding that new relationships and the number of key banks tend to have a persistent effect on borrowing and lending, our results provide an additional mechanism that may partly explain the collapse in international capital flows during the crisis and the fact that it was especially pronounced in

${ }^{5}$ This finding is consistent with that in Peek \& Rosengren $(2000)$ for the case of Japan.

${ }^{6}$ As Rose \& Wieladek (2011) demonstrate, some of this decline may be due to an increase in financial protectionism associated with massive injections of public funds into banks during the crisis. 
emerging markets (Milesi-Ferretti \& Tille, 2011) 7

Our paper also has a methodological implication for the active literature on the stability of banking network. Many recent papers on financial networks analyze the potential for the spread of contagion in various exogenous network structures using simulation methods (Battiston et al. 2009; May \& Arinaminpathy, 2010; Mirchev et al., 2010; Nier et al., 2007; Sachs, 2010). Others empirically analyze the structure or the development of country-specific and global banking networks (Cocco et al., 2009, Craig \& von Peter, 2010; Garratt et al., 2011; von Peter, 2007). A handful of papers model how relationships between banks form networks endogenously (Allen \& Gale, 2000, Castiglionesi \& Navarro, 2007; Delli Gatti et al., 2010). The findings of our paper contribute to this literature by showing that the structure of a global banking network responds to economic and financial shocks, and therefore it may not be appropriate to model banking networks as static or exogenous, especially when analyzing the effects of financial shocks.

The paper is organized as follows. Section 2 presents our data and methodology, mostly focusing on the construction of the global banking network and the network statistics. Section 3 describes the evolution of the network structure over time. Section 4 presents a stylized model of the formation of bank relationships. Section 5 presents the results of our regression analysis. Section 6 concludes.

\section{Constructing global banking network}

In the wake of the global financial crisis, the complex structure of bank relationships started to garner attention in the literature. One direction of this analysis turned to representing banking systems as graphs, or networks 8 This literature mostly focuses on the short-run aspects of connections

\footnotetext{
${ }^{7}$ For comprehensive analysis of factors affecting global capital flows during the crisis and the recovery, see Fratzscher (2011).

${ }^{8}$ Some recent papers are Chan-Lau et al. (2009); Haldane (2009) and Haldane \& May (2011). The application of the network approach to financial markets follows recent literature on networks in social interactions and firm
} 
between banks, that is, liquidity exposures of banks to one another, the topology of which affects the stability of the banking system and the propagation of the shocks. As discussed above, in this paper we take a longer-run view of connections between banks, interpreting lending relationships as connections that facilitate information flows.

Unlike much of the recent empirical analysis of banking and financial networks that build on aggregate country-level bilateral bank lending from the Bank for International Settlements (BIS) data and bilateral asset holdings from the International Monetary Fund's (IMF) Coordinated Portfolio Investment Survey (CPIS) (Garratt et al., 2011; Kubelec \& Sá, 2010; Minoiu \& Reyes, 2011; von Peter, 2007), this paper constructs a global banking network at the bank level, something that has not been done before $9^{9}$ There are two main reasons why loan-level data are more suitable for the construction of the network than BIS statistics. First, the BIS reports stocks of claims and does not provide information on the origination time of these claims. The BIS computes "flows" as a change in stocks, and therefore such flows include, in addition to loan origination, repayments and changes in valuations of these stocks. As a result, such data cannot provide clean information on the formation of new relationships between banks (or countries, in case of BIS data). Second, country-level data do not distinguish between cases with many loans of smaller amounts made in many different pairs of banks and cases where only a few large loans are made between a small number of bank pairs. Loan-level data address both of these concerns - they give the date of the loan origination and allow us to compute network statistics at the bank level.

We assume that each loan from bank to bank creates a relationship, or link, thus contributing to the network. Our data consist of syndicated bank loans with median maturity of about 5 years.

theory. Karlan et al. (2009) offers a theoretical model of networks in social interactions, while papers by Bottazzi et al. (2009); Guiso et al. (2009) and Lehmann \& Neuberger (2001) provide some discussion of the importance of trust and social interactions for investment, economic exchange, and lending. The work on social capital pioneered by Putnam (1995) is the seed of much of this literature.

Craig \& von Peter (2010) use data from the German interbank market to test for tiering in the banking network; Cocco et al. (2009) build, for the Portuguese interbank market, "borrower preference" and "lender preference" indexes based on loans between banks, but do not go so far as to create a network of banks, which would take into account indirect relationships. 
Thus, the relationships we define are long-term relationships between banks. In constructing a cumulative network panel by adding new loans to the ones that existed in the prior year we implicitly make an assumption that relationships between banks that are established through lending persist even if the loan is repayed.

\subsection{Data sources and manipulation}

Dealogic's Loan Analytics database (a.k.a. Loanware) provides information on international syndicated bank loans (with some domestic syndicated loans included as well). It has exhaustive information on the terms of the loan, as well as some information on borrowers and lenders. From this database, we downloaded information on loans extended between January 1, 1980, and December 31, 2009, to private- and public-sector banks, a total of 15,324 loans. Out of these, 84 loans had to be dropped due to missing deal values and 151 had to be dropped due to missing lenders field, which left us with the total of 15089 loans.

The Loan Analytics database provides information on syndicated bank loan origination, including loans extended to financial institutions. For our purposes, syndicated loans are a good proxy for bank relationships because they tend to be of much longer maturities than interbank loans and thus represent a larger commitment and the potential for information flows. The bank-to-bank syndicated loan market is relatively large - in the late 1990s syndicated bank loans extended to banks and reported in Loan Analytics amounted to over 30 percent of total bank claims on banks as reported by the BIS. This ratio fell to below 20 percent by the end of our sample as interbank lending ballooned prior to the global financial crisis. In 2007, prior to the crisis, 4.7 trillion USD worth of syndicated loans were extended to banks (see Figure 1) ${ }^{10}$

\footnotetext{
${ }^{10}$ BIS reports in its Table 10 in the Annex to Quarterly Report "total amount of syndicated loans signed," which is substantially smaller than what we find in our data. This is because BIS excludes the following loans: all loans with maturity less than three years, all loans where there is only one lender, and all loans where nationality of all lenders is the same as that of a borrower. This excludes a large portion of the loans, especially taking into account that BIS includes loans to nonfinancial institutions in its Table 10 data.
} 
We retained the following variables: name of the borrower or borrowers (327 loans had multiple borrowers), deal nationality, all bank involvement (list of all lenders, administrators, and lead arrangers), loan signing date, and total deal value in millions of U.S. dollars, which we deflate by the seasonally adjusted U.S. consumer price index (CPI) from the U.S. Bureau of Labor Statistics. Since the loans are syndicated, they have on average about seven participants, with the median of two participants. Because information on individual lender participation is only available for a handful of the cases, we split each loan amount equally among lenders and then among borrowers, in the case of multiple borrowers, replicating observations for each borrower-lender pair and dividing the total deal value equally among all pairs. We then collapse our data by borrower-lender pair in each year, adding up the amounts, so that in each year each borrower-lender pair enters only once.

Our list of loans, thus, includes 4880 unique institutions (banks and nonbanks) as lenders only, 2535 unique banks as borrowers only, and 1110 unique banks that appear as both borrowers and lenders, for a total of 8525 banks 11 For 7938 of the banks we were able to confidently match banks to countries ${ }^{12}$ We link each banking entity to a country on a locational basis, treating each subsidiary or branch as a separate entity 13

\subsection{Constructing networks}

To construct our noncumulative panel of network statistics, we create a separate network for each year. To do so, for each of the 30 years covered in the data, we create a list that has only three elements: borrower, lender, and nominal loan amount, referred to as the "edge list." Using a custom Mata code for Stata (Miura, 2010), we create for each year a network and compute network

\footnotetext{
${ }^{11}$ While we are restricting borrower type to be a bank, for technical reasons we cannot restrict lenders to be banks. In our data set, out of 5990 lenders (including those that also appear as borrowers), a maximum of 1710 are nonbanks, e.g., insurance companies and special purpose vehicles.

${ }^{12}$ If a given institution was associated with country $\mathrm{X}$ in one observation and country $\mathrm{Y}$ in another, we eliminate both observations.

${ }^{13}$ Mian 2006) shows that cultural and geographical distances between headquarters and local branches play an important role.
} 
statistics at the network and bank-level as described below ${ }^{14}$ We construct for our regression analysis a bank-year panel, heavily unbalanced, by combining each year's network statistics for each bank in one data set.

For cumulative panel, we create a set of edge lists, where for each subsequent year we add loans to those in previous years. Thus, we have edge lists including loans extended in 1980, 1980 and 1981, 1980 through 1982, etc. all the way through the full set of loans extended between 1980 and 2009. From each edge list we, once again, construct a network, but this time the network is larger every year and the network statistics for year $t$ are based on the network made out of loans between 1980 and $t$. We combine this information into a cumulative bank-year panel and compute percentage changes in network statistics for each bank for each year from a previous year. The cumulative panel contains more observations because once a bank enters the network, it stays in the network throughout the sample.

Note that our networks are directed, that is the direction of relationship matters, in that bank A borrowing from bank B is not the same as bank B borrowing from bank A. For both noncumulative and cumulative panels we also construct country-level data sets of weighted averages of network statistics using as weights the amounts borrowed and lent by each bank, converted to U.S. dollars using the exchange rate on the day the loan contract was signed and deflated by the monthly U.S. CPI 15

\section{$2.3 \quad$ Network statistics}

Some terminology needs to be introduced to describe precisely the network statistics used in this paper. The vertices (nodes) of the network, banks in our case, are indexed by $i=1, \ldots, I$. The edges (direct connections) between each pair of nodes $i$ and $j$, loans in our case, are denoted by $c_{i j}$,

\footnotetext{
${ }^{14}$ We check our computations, when possible, against MatlabBGL version 4.0, which makes use of the Boost Graph Library.

${ }^{15}$ Detailed information at the country-year level is available in the Electronic Appendix.
} 
which is binary $\{0,1\}$. Not every pair of nodes is connected by edges. The edges carry the weights which measure the intensity of the connection, or loan amount, which we denote as $w_{i j}$. Note that $w_{i j}>0$ if $c_{i j}=1$ and $w_{i j}=0$ if $c_{i j}=0$. The edges are directed so that $c_{i j} \neq c_{j i}$ and $w_{i j} \neq w_{j i}$. We will denote $c_{i j}$ and $w_{i j}$ as connections going from node $i$ to node $j$, i.e. a loan from bank $i$ to $\operatorname{bank} j$.

A path between each pair of nodes $i$ and $j$ is a sequence of edges that connect $i$ to $j$. There could be many paths connecting each pair of nodes and, because the network is directed, paths from $i$ to $j$ do not generally coincide with paths from $j$ to $i$. For our purposes, the length of a path is the number of edges that comprise that path regardless of the weight; the weight is only used later when we aggregate network statistics across banks. A geodesic path is a path between two given nodes that has the shortest possible length. We denote the length of the geodesic path from node $i$ to node $j$ as $g_{i j}$. Note that each pair of nodes $i$ and $j$ can have more than one geodesic path which will, by definition, have the same length. Because the network is directed, there are pairs of nodes for which there is a path in one direction but not in the other. We denote the number of geodesic paths from $i$ to $j$ as $p_{i j}$. We denote the number of geodesic paths that go from $i$ to $j$ through $k$ as $p_{i k j}$.

We first construct the statistics that describe the network as a whole

- Density is the number of edges as a share of possible number of edges: $\sum_{i} \sum_{j}\left(c_{i j}+\right.$ $\left.c_{j i}\right) /(N(N-1))$. Density is $\in[0 ; 1]$ and describes how connected the nodes are within the network, it is sometimes referred to as connectivity or connectedness of a network;

- Diameter is the length of the longest geodesic path in the network: $\max _{i j} g_{i j}$. It measures the span of the network;

We next calculate the following measures for each node:

- OutDegree is the number of edges originating from node $i$ : $\sum_{i} c_{i j}$; 
- InDegree is the number of edges terminating in node $i: \sum_{i} c_{j i}$;

- Betweenness is the average ratio of geodesic paths between any pair $j$ and $k$ that go through node $i$ to the total number of geodesic paths between $j$ and $k: \sum_{j} \sum_{k}\left(p_{j i k} / p_{j k}\right)$.

In- and outdegree statistics measure how many direct connections each bank has in terms of borrowing and lending, respectively, that is how many lenders and borrowers each bank has. Betweenness measures how central the bank is in terms of intermediating bank flows. We define a Key bank as bank that has positive betweenness. To identify newly formed relationships and changes in a bank's status as a key bank, we simply take first differences in these variables in the cumulative network.

Table 1 shows that these statistics are important measures of connections between banks in terms of bank lending. In columns (1) and (2) we present the results of the estimation of bank fixed effects regression of borrowing and lending, respectively, on contemporaneous and lagged indicators of whether a bank has established a new borrowing or lending connection. Since all the information in our data is based on the loan origination, an increase in borrowing or lending in a given year is entirely due to a new loan facility and is not automatically related to the loan that was made when connection was established initially in prior years. We find that adding a new lender increases bank's borrowing through new loan origination in the following three years, while adding a new borrower increases bank's lending through new loan origination in the following two years. We find that becoming a key bank does not substantially affect that bank's future lending or borrowing 16

In columns (3) and (4) we present the results of the country fixed effects regression of country total borrowing and lending on contemporaneous and lagged number of key banks in that country. Once again, in each year borrowing and lending reflects only new loan origination. We find that an increase in the number of key banks in a country leads to a persistent increase in both borrowing and lending amount by this country. In contrast to the effects on individual banks, average number

\footnotetext{
${ }^{16}$ Controlling for the key bank status in these regressions does not alter the results.
} 
of new borrowing and lending connections in a country does not have an effect on future borrowing and lending by this country ${ }^{17}$

\subsection{Recessions and banking crises}

To identify years with recessions in the U.S., we use NBER recession dates. To identify local recessions we use data on real GDP growth from the IMF's International Financial Statistics (IFS) (line 99b) with missing observations filled in with World Economic Outlook (WEO) data if available. Since IFS does not report the data for Iceland and Taiwan, we take these series entirely from WEO. We construct the indicator of local recessions as equal to one whenever the GDP growth rate is below its linear trend, which is a broader definition than is commonly used but a transparent one and feasible to compute for most countries 18

Dates of systemic banking crises are taken directly from Laeven \& Valencia (2008), which means that 2008 and 2009 are not coded as banking crises in any country. This is not a problem, however, because in all regressions we will include dummy variables for 2008 and 2009. In the regression analysis we lag recession indicators and a banking crisis indicator by one year 19

\section{Evolution of the global banking network}

We begin our analysis informally, by plotting measures of the network size and connectivity for each year for cumulative and noncumulative networks over time to see any trends and the effects of U.S. recessions and of the global financial crisis in 2008-2009. Figure 2 presents measure of the size of the network, while Figure 3 presents measures of connectivity.

\footnotetext{
${ }^{17}$ Controlling for the average number of new lenders or borrowers in a country does not affect the results of these regressions.

${ }^{18}$ For the US, 1995, 2002, and 2007 are classified as recession years by our definition, in addition to all the years identified as recession years by NBER.

${ }^{19}$ Electronic Appendix provides complete data on recessions and banking crises in our sample.
} 
The top panel of Figure 2 plots as a line the number of banks that either borrowed or lent, or both, in each year in our sample, based on noncumulative network panel, and as bars a number of new banks that entered the GBN in each year, based on cumulative network panel. We can see that bank entry slowed down in the decade prior to the global financial crisis. We can also see the decline in the total number of banks after 1997, partly driven by a wave of banks' mergers and acquisitions 20

The middle panel of Figure 2 plots the total number of connections between banks in each year, and the number of new connections. We can see that until the mid-1990s most connections in the network were due to new connections made rather than connections between banks that have interacted with each other in the past. The share of new connections declined in the decade prior to the global financial crisis. We can also see a very pronounced drop in connections between banks during the crisis, both in terms of total number of connections and in terms of number of new connections formed.

The bottom panel of Figure 2 demonstrate that despite the decline in the total number of banks in the network in recent years, country representation continued to grow with banks from new countries entering the GBN and more and more countries participating in the syndicated lending activity in each year. In the largest network we constructed, cumulative network as of 2009, there are banks from 141 countries. Most of this growth in the number of countries is accounted for by the dissolution of the Soviet Union and Yugoslavia, and by the entry of the African and Central American nations into global capital markets.

All three panels of Figure 2 show quite clearly two periods of rapid expansion of the GBN. First occurred in the early 1990s and the second in the first six years of this century. These two episodes are frequently characterized as lending booms in the literature. Here we show that not only the volume of lending grew rapidly during these periods, but also lending and borrowing was

\footnotetext{
${ }^{20}$ In the U.S. the wave of bank mergers was precipitated by Riegle-Neal Act of 1994 (Pilloff, 2004).
} 
conducted by more and more banks to and from more and more new counterparties. The latter is demonstrated by a growing number of new connections during these periods, which, as we have argued in the previous section, in itself has likely contributed to increasing globalization of capital flows and volume of lending activity.

Figure 3 describes the dynamics of network connectivity. We observe an increase in the density of the network, that is more connections on average per bank during the period when the number of banks was rapidly declining. The smooth decline of the density of cumulative network is simply driven by the network expansion over time. We can also observe that not only new connections were made in the network throughout our sample period, but that the span of the network increased to reach 18 at its peak in 2007. During the global financial crisis, however, the network has shrunk the only way this can be observed in the cumulative network is when new direct connections are made between banks that were previously connected through a longer chain.

We defined a key intermediary, or a key bank, as a bank that acts as the only connection between at least one pair of other banks. While we can see an overall trend increase in the number of key banks in the network as a share of total number of banks, this trend is partly driven by the declining number of banks in the network. We can see that the number of new banks that act as key intermediaries is very small after 1990. In fact, less than 1 percent of new banks in the network in each year are key banks. In addition, we see a rapid increase in the number of key banks in the years just prior to the global financial crisis, reaching over 10 percent at its peak in 2007 prior to its collapse to just 6 percent during the crisis. As we saw in the previous section, the number of key banks in a given country is positively associated with borrowing and lending in the subsequent years, meaning that the structure of the GBN was likely amplifying the global credit cycle.

The final chart on Figure 4 shows the average number of direct links banks in the network have and the number of new links they make every year. Ivashina \& Scharfstein (2010) demonstrated for the sample of U.S. syndicated loans to corporations that the number of lenders in a given syndicate 
decline during the global financial crisis. We see this decline in our sample as well - the median number of participants in a syndicate fell from 4 to 2 between 2007 and 2009. By construction, this would result in the decline in the average number of direct connections in the GBN. We see, however, that the decline in the number of connections during the crisis was larger than what can be accounted by the changing syndicate size. More importantly, very few new connections were made, and in 2009 the average number of connections in the cumulative network actually declined, which can only be due to the composition effect — new banks that entered the GBN in 2009 entered with fewer connections than existing banks had on average.

All charts in Figures 2 and 3 show shading for U.S. recessions. We can see that during U.S. recessions the number of connections and especially the number of new connections in the GBN tend to decline. This is evident on the middle panel of Figure 2 and the SE panel of Figure 3. We can also see that the diameter of the network is smaller during U.S. recessions and that the number of key intermediaries tends to fall. We can see very prominently that there are almost no new key banks and no new connections made during U.S. recessions. These observations, however, can be driven by overall decline in bank lending activity and not really reflecting the structural changes in the network. For this reason, we will analyze the effects of U.S. recessions and the global financial crisis on formation of new relationships and on the number of key banks in the regression setting, which allows us to condition on total borrowing and lending, time trend, as well as country and bank fixed effects.

\section{A simple model of bank relationships}

Before turning to the regression analysis, to fix ideas on how macroeconomic shocks can affect bank relationships, we present a stylized model of bank relationship formation. It takes the macroeconomy as given but allows international bank relationships to form endogenously. In our model banks have to establish relationships with banks in a foreign country in order to finance foreign 
projects - our short-cut for the idea that banks facilitate capital flows between countries through intermediation or otherwise.

\subsection{Model setup with no relationships, one period}

Suppose the world consists of two countries, home and foreign. We denote variables pertaining to the foreign country with *. In each country, banks finance investment projects, which have heterogeneous returns $R$. We assume that banks can perfectly select projects with the highest available return and therefore the return on the marginal project financed is a declining function of the number of projects financed: $R^{\prime}(x)<0, R^{\prime \prime}(x)>0$, where $x$ is the number of projects financed. We allow this function to be different in the foreign country, but have the same properties: $R^{* \prime}(x)<0, R^{* \prime \prime}(x)>0$. We assume that projects succeed with probability $\pi$, and otherwise fail with zero return. We assume that the probability of success is the same in both countries but varies by the state of nature - it can be either high $\pi_{H}$ with probability $1-\rho$ or low $\pi_{L}$ with probability $\rho$. We interpret the state of nature with a low probability of success as recession, and $\rho$ as recession probability. Thus, the expected return on marginal project $x$ is $\left((1-\rho) \pi_{H}+\rho \pi_{L}\right) R(x)=\phi R(x)$, where $\phi=(1-\rho) \pi_{H}+\rho \pi_{L}$.

There are $N$ and $N^{*}$ identical risk-neutral banks in domestic and foreign countries that face exogenous costs of funding: $D$ and $D^{*}$, respectively. They decide whether to invest in domestic projects, foreign projects, or not to invest at all. Each bank can only finance one project. In order to invest in a project in a different country, a bank has to pay a fee $F$ to a bank in that country for intermediation. For simplicity, we assume that banks either invest in projects or serve as intermediaries. Since banks that intermediate do not invest their own money, they don't have to pay costs of funding. Thus, we also assume that the cost of intermediation is zero and that the only cost associated with intermediation is an opportunity cost of not being able to finance a domestic project. Banks that choose to invest in foreign projects have to pay an intermediation fee 
in addition to the cost of funding prior to realization of the return on the project. We denote as $\alpha, \alpha^{*}$ the share of banks that finance domestic projects.

Autarky. Suppose $N$ and $N^{*}$ are sufficiently large so that $\phi R(N)<D$ and $\phi R^{*}\left(N^{*}\right)<D^{*}$. Because of an additional fee required to finance foreign projects, in this case $\alpha$ and $\alpha^{*}$ solve $\phi R(\alpha N)=D$ and $\phi R^{*}\left(\alpha^{*} N^{*}\right)=D^{*}$. This is a market equilibrium as well as the social optimum because only projects with positive expected net returns are financed and all of such projects are financed at a minimum cost. We abstract from the question of which banks do and which do not end up financing projects. One can think of either random or sequential assignment, it does not affect the predictions of the model.

Foreign financing. In order to construct an equilibrium in which foreign financing is present, we simply assume that the foreign country does not have a sufficient number of banks, so that even if all banks engage in financing, the marginal project will still have a positive expected net return, that is $\phi R^{*}\left(\alpha^{*} N^{*}\right)>D^{*}$. One can interpret this assumption in a number of ways: as representing an underdeveloped financial system in foreign country; as representing a lower level of economic development in a foreign country, and thus higher return on investment; as a lower level of savings, for institutional or other reasons, which limits the amount of domestic funds available for investment.

In the home country all projects with positive net expected returns will be financed by home banks, so that $\alpha$ is still given by $\phi R(\alpha N)=D$. For the marginal bank to be indifferent between financing a domestic or a foreign project, the expected return on the foreign project should be equal to the expected return on the home project. These returns will be zero unless there is still a positive net return on foreign projects after all interested home and foreign banks have chosen to invest in them - this case is less interesting, so we assume $N$ is sufficiently large to rule it out. Given that $\alpha$ is the share of home banks investing in domestic projects, denote as $\delta(1-\alpha)$ 
the share of all domestic banks that choose to invest in foreign projects. This gives us demand for intermediation.

Foreign banks have a choice between financing their domestic projects or intermediating. We assume that all foreign banks that do not invest in domestic projects have an equal chance of intermediating, which they take as given. Thus, in equilibrium foreign banks will be indifferent between the expected returns from investing in their domestic projects and the expected fees from participating in the intermediation lottery. Thus, supply of intermediation is jointly determined with financing of foreign projects by foreign banks.

The total number of home projects financed will still be $\alpha N$, while the total number of foreign projects financed will be $\alpha^{*} N^{*}+\delta(1-\alpha) N$. The equilibrium is thus a triplet $\left(\alpha, \alpha^{*}, \delta\right)$ that solves the following equations

$$
\begin{gathered}
\phi R(\alpha N)=D, \\
\phi R^{*}\left(\alpha^{*} N^{*}+\delta(1-\alpha) N\right)=F+D, \\
\frac{\delta(1-\alpha) N}{\left(1-\alpha^{*}\right) N^{*}} F=\phi R^{*}\left(\alpha^{*} N^{*}+\delta(1-\alpha) N\right)-D^{*} .
\end{gathered}
$$

\subsection{Many periods and formation of relationships}

To introduce the value of relationships, we need to extend the benchmark model to include multiple periods. To keep the model simple, we will assume that banks that experience a bad realization of the project they finance simply exit and are replaced by the same number of banks that are identical to those remaining. This way, the number of banks in each country remains constant and we don't have to keep track of each bank's status. The only thing that will be carried from one period to the next is relationships established through intermediation.

For the value of the relationship to be positive, we will assume that the cost of intermediation for banks that have already been engaged in the financing of foreign projects is smaller than the cost 
of intermediation for banks that are entering the market of financing foreign projects. In particular, we will keep the intermediation fee for new entrants at $F$ and will assume that banks that have already established a relationship will only pay $f<F$ in each of the periods when they choose to finance foreign projects. We will make a slight change for the purpose of model interpretation by allowing $\phi$ in the home country to be different from $\phi^{*}$ in the foreign country.

We consider an equilibrium with an interior solution, as above, in each period. Period $t$ will start with $\gamma_{t} N$ banks in the home country that have financed foreign projects in period $t-1$; $\gamma$ represents the share of home banks that have established relationships with foreign banks in previous periods. These banks have a lower cost of financing foreign projects in period $t$ than other banks and we assume that they will always choose to finance foreign projects. Thus, $\gamma_{t}=$ $\pi_{t-1}^{*}\left(\gamma_{t-1}+\delta_{t-1}\left(1-\gamma_{t-1}\right)\right)$, where $\pi_{t-1}^{*}$ is the realization of project success probability in the foreign country in period $t-1$ and is therefore the probability that a bank that established relationships in period $t-1$ will survive in period $t, \gamma_{t-1}$ is the share of banks that already had relationships at the start of period $t-1, \delta_{t-1}$ is the share of banks that neither had prior relationships nor were financing domestic projects that chose to finance foreign projects in $t-1$ (and pay the fee $F$ ). In each period, therefore, $\gamma$ is predetermined. Since all time periods are a priori identical, we will drop the time subscript.

There is now an additional value to financing foreign projects - the value of relationships that will with probability $\phi^{*}$ bring rents next period and in every following period $s$ with probability $\phi^{* s}$ in the amount of $F-f$. This implies the present value of the relationship, $V_{t}=\sum_{s=t+1}^{\infty}(F-f)=$ $\frac{\phi^{*}}{1-\phi^{*}}(F-f) \forall t$.

In the benchmark model, the zero-profit condition for the home banks makes the number of new connections independent of home economic conditions - whenever $\alpha$ changes to satisfy equation (1), $\delta$ adjusts accordingly. Since we are interested in the effects of home economic conditions on bank relationship, we make another modification to our benchmark mode here, assuming that 
regardless of the number of home projects financed they pay fixed returns $\bar{R}$ in the case of success, thus expected return on the home project is $\phi \bar{R}$. We assume that $\bar{R}$ is sufficiently small so that a) home banks with existing relationships still prefer to invest in foreign projects, and b) foreign banks are still not interested in investing in home projects. The choice of $\alpha$ is now irrelevant share $\delta$ of banks that don't have relationship will invest in foreign projects, the rest of them will invest in home projects.

In equilibrium with an interior solution, home banks without relationships will be indifferent between financing domestic projects or foreign projects. Foreign banks with relationships will collect a smaller intermediation fee than banks that provide intermediation for new foreign projects financing banks. To make the model interesting and keep it simple, we will assume that foreign relationship banks all engage in financing of their domestic projects in addition to collecting the fee of $f$. This assumption represents a possibility that maintaining relationships is less costly for the intermediary than establishing new ones, and thus there is no opportunity cost of maintaining existing relationships.

As before, remaining $N^{*}-\gamma N$ foreign banks are indifferent between financing their domestic project and entering the lottery for intermediation of new foreign investments by home banks, given that $\gamma N$ domestic projects are already taken by relationship banks. Share $\alpha^{*}$ of these remaining banks will finance projects, while the rest will enter the lottery. Denote the number of new connections formed as a share of $N, \nu=\delta(1-\gamma)$. Then the total number of foreign projects financed will be $\gamma N+\alpha^{*}\left(N^{*}-\gamma N\right)+(\gamma+\nu) N$. The equilibrium for each period is thus a pair $\left(\alpha^{*}, \nu\right)$ that solves the following equations given $\gamma$

$$
\begin{gathered}
\phi^{*} R^{*}(\Psi)+V=F+\phi \bar{R}, \\
\frac{\nu N}{\left(1-\alpha^{*}\right)\left(N^{*}-\gamma N\right)} F=\phi^{*} R^{*}(\Psi)-D^{*},
\end{gathered}
$$


where $\Psi=\alpha^{*}\left(N^{*}-\gamma N\right)+(2 \gamma+\nu) N$ is the total number of projects in the foreign country that are financed by all banks.

The Appendix shows that this equilibrium will be stable as long as $\phi \bar{R}-D^{*}>V$ and presents the conditions that need to hold for the solution to be in the interior, that is $0<\alpha^{*}<1,0<\nu<1$. It also presents all the derivatives used for comparative statics below.

An expected equilibrium path can be computed using the fact that in expectation $\gamma$ should be the same in all periods. Thus an expected equilibrium path is values of $\left(\alpha^{*}, \nu, \gamma\right)$ that solve equations (4)-(5) and

$$
\gamma=\phi^{*}(\gamma+\delta(1-\alpha-\gamma))=\phi(\gamma+\nu)
$$

We will interpret changes to one-period equilibrium described by equations (4)-(5) as short-run effects and changes to the expected equilibrium path as long-run effects.

\subsubsection{Interpretation and comparative statics}

We will now consider the interpretation of our model and the implications of parameter changes for the expected equilibrium path as well as for each period's equilibrium. As we are interested in banking crises and business cycles, we consider the effects of the following perturbations:

Recession-demand: a bad state of nature (realization $\pi=\pi_{L}$ ) could be thought of as a recession that is due to an adverse demand shock, as fewer projects are successful. The only effect of such a shock in a foreign country will be to lower $\gamma$ in the beginning of the period. We can also think of a permanent adverse demand shock that would increase $\rho$, a probability of the bad state of nature, and thus lower $\phi$ in case of the home country and $\phi^{*}$ in case of the foreign country.

Recession-supply: we can model a supply-side recession as a decline in returns on projects for any given number of projects financed, that is, decline in $R(\cdot)$ or $R^{*}(\cdot)$. 
Cost of funding: we can think of an increase in the cost of funding $D$ and $D^{*}$ as banking crises in home and foreign countries, respectively.

Intermediation fees: we can think of a global banking crisis as an increase in the costs of intermediation, especially in the cost of establishing new connections, $F$, which can be interpreted as an increased counterparty risk premium, although we do not model such risk specifically. An increase in $f$ for a given $F$ can be thought of as a decreased value of relationships for lenders, which could also be an outcome of a crisis in banks' confidence.

The Appendix shows formally the effects of these perturbations on the number of new connections formed, $\nu$. Here we provide an informal discussion and intuition of the results.

A temporary adverse demand shock in the foreign country would lead to a larger than usual destruction of existing relationships, both in home and in foreign countries. As a result, more new connections will be made in the following period. A permanent adverse demand shock in the foreign country, that is, a lower average probability of project success, would lead to a decline in the number of new connections made, both in the short and, to a lesser extent, in the long run. A permanent adverse supply shock in the foreign country, that is, a lower return on projects for any given number of projects financed, would lead to a decline in the number of new connections made both in the short and the long run.

Overall, the model predicts that while a temporary demand shock would lead to an increase in the number of new connections, recessions that are more long-lasting, regardless whether they are demand- or supply-driven, will result in the reduction of the number of new connections. The intuition from this result is as follows - temporary shocks may destroy existing connections that need to be replaced, giving a temporary boost to the number of new connections made. In the long run, however, a reduction in profitability of investing in the foreign country is more important, reducing the incentive for home banks to form new connections. 
Permanent adverse demand or supply shocks in the home country increase the number of new connections formed as more home banks turn to financing foreign projects due to a now lower opportunity cost of not investing in home projects.

A local banking crisis exhibited as an increase in the cost of funding in the foreign country will give comparative advantage to home banks and therefore lead to an increase in the number of new connections formed. While in our benchmark model an increase in the cost of funding in the home country would lower the number of new connections formed by giving comparative advantage to foreign banks, in this set-up home banks incur the same cost of investing in home and in foreign projects and therefore this cost has no effect on the number of new connections.

An increase in the cost of intermediation holding the value of relationship constant has an ambiguous effect on a number of connections formed. This result comes from the fact that home banks are discouraged from forming new connections by the higher intermediation fee, while at the same time the intermediation fee is received by foreign banks as pure rent and thus an increase in this fee reduces the number of foreign banks that are willing to finance their domestic projects. For the resulting effect to decrease the number of new connections formed we would need to assume that return on foreign projects declines quickly with an increase in the number of projects financed, so that the effect on home banks dominates. A decline in the value of the relationship holding the intermediation fee constant would lead to fewer new connections made, quite intuitively.

Translating these findings to empirical terms, we interpret the home country as the U.S., or a core country in the global banking network. We find that local recessions in countries other than U.S. are likely to increase the number of new relationships established by banks initially, but then lower it as lost connections are replaced. A recession in the U.S. would increase the number of new connections made by U.S. banks. A local banking crisis that results in a higher cost of funding for banks would lead to an increase in the number of new relationships formed. In case of a global banking crisis, which we could think of as a destruction of trust between banks that lowers the 
value of relationships, fewer new connections will be made.

The above model does not create a network of relationships, but it is clear that it could be extended to include more countries. Differences in the returns to projects, in costs of funding, as well as the wedge that arises from intermediation fees would allow for a given country's banks to receive foreign investment from a country with more banks while at the same time investing in the country with fewer banks. Consistent with findings in the literature that banking networks tend to have a core-periphery structure, we would obtain a network with countries that only receive funding on the periphery and countries that receive funding and also fund foreign projects in the core. All of the intuition obtained in the two-country model could readily be extended to such a network.

\section{$5 \quad$ Regression analysis}

We analyze the formation of new connections in a regression setting. Because we are interested in the incremental effects of recessions and crises on the structure of the global banking network, we conduct our regression analysis on the bases of cumulative network panel, where we look at first differences of the network characteristics.

We begin by a simple time series analysis where we do not distinguish between countries and analyze the effects of recessions and crises on the global banking network as a whole. Next we turn to country-level analysis, where we study how recessions and banking crises in a given country affect new connections formed by this country's banks and the number of key banks in that country. In these regressions we control for country fixed effects and split our sample into industrial and developing countries. Finally, we conduct a bank-level analysis, with bank fixed effects, where we study how the probability of a new connection by an individual bank, the probability that bank becomes a key bank, and the number of new connections it form is affected by banking crises and 
recessions. For all regressions conducted at the bank level we clustering standard errors on country to avoid downward bias (Moulton, 1990). The results are reported in Tables 2 through 4.

Even though our full network consists of 141 countries and 7938 banks, we don't want offshore financial centers and countries with only a few banks to affect our analysis. While all the network characteristics are computed using the full sample, in the regression analysis we only retain countries that are not classified as offshore financial centers in Rose \& Spiegel (2007) and that had at least 90 observations in our data (that is, on average at least 3 banks per year in 30 years in the cumulative network) 21

\subsection{Time-series regressions}

The top panel of Table 2 presents the results of our time series regressions. We are considering the dynamics of four variables - number of new banks in the GBN, average number of new lenders (i.e. new borrowing connections) each bank has, average number of new borrowers (i.e. new lending connections) each bank has, and the number of new key banks in the network. In network lingo, these correspond to the change in the number of nodes, change in average indegree, change in average outdegree, and the number of nodes with positive betweenness that either had zero betweenness or did not exist in the previous year, all computed based on cumulative network panel. We compute these numbers for the network as a whole and thus we have one observation per year.

We estimate an OLS regression for each of these variables, computing robust standard errors to allow for heteroschedasticity. Because the number of new keybanks is rather small, especially once we move to the country-level regressions, we also estimate a count regression, using negative binomial (NB) specification for the number of new key borrowers. The interpretation of coefficients is different, but as comparison of columns (4) and (5) of Table 2 reveals, qualitatively the results are

\footnotetext{
${ }^{21}$ List of countries in our regression sample is provided in the Electronic Appendix.
} 
the same. In this time series specification we cannot reject a simpler version of the count model, a Poisson regression, but as we move on to other specification, we definitely observe over-dispersion, which explains our choice of the NB model 22

In all regressions we control for change in total borrowing. In aggregating the full network it has to be equal to total lending by construction. Since we excluded some of the countries from the regression analysis, it is not identically equal, but very closely correlated. As we can see, change in total borrowing only enters significantly in the regressions with the change in number of banks or change in number of key banks as a dependent variable. Since the number of new lenders and of new borrowers is the average number per bank, it is invariant with respect to the overall lending in the network.

We also control for linear trend. This may potentially raise a concern with respect to our estimates of the effects of the global financial crisis. Indeed, given that the crisis is at the very end of our sample period, a positive trend would exaggerate the decline during crisis. As it turns out, however, in all regressions the estimated slope of the trend line is negative thus potentially biasing down the effects of the global financial crisis. If we re-estimate the regressions without including trend, we find very large and strongly significant coefficients on 2008 and 2009 in all regressions. We choose to be conservative in our approach and proceed to include trend in all our regressions as a benchmark 23

Given only 29 observations in the regression, we do not have much power to estimate the effects precisely. We do see, however, patterns consistent with the predictions of our model. Following U.S. recessions there is more new connections in terms of both borrowing (new lenders) and lending (new borrowers), while a larger number of local recessions and banking crises are associated with fewer new connections made in the subsequent year. In fact, the decline in the average number of

\footnotetext{
${ }^{22}$ Estimating this same regression imposing Poisson distribution does not affect the results. It allows, however, to compute pseudo- $R^{2}$, which in this case is equal to 0.35 .

${ }^{23}$ Including quadratic trend instead produces results very similar to those with linear trend and estimates of the coefficient on the quadratic that are very close to zero.
} 
borrowers is statistically significant. We also observe a decline in the number of key banks in the network in the aftermath of all events, and a particularly large and strongly statistically significant decline in 2008. According to linear specification, the decline in the number of key banks in 2008 was 18, more than one standard deviation (13), while according to marginal effects of the NB regression, the number of key banks in 2008 was 54 percent smaller than on average in the sample (the incidence rate ratio corresponding to this coefficient is 0.46 ).

The effect of the U.S. recessions on the formation of new connections, while consistent with the model prediction, seems to be at odds with our informal analysis of Figures 2 and 3. This results arises from the fact that in the regressions we now condition on trend as well as recessions and banking crises in other countries, all of which have a negative impact on the number of new connections. Other results are consistent with our graphical analysis.

\subsection{Country-level regressions}

Bottom panel of Table 2 presents the analysis of the same set of variables in the country panel. Now all variables are computed as sums or averages for each country in each year. Since borrowing is no longer identical to lending, we include both change in lending and change in borrowing as controls (the correlation between change in lending and change in borrowing in this sample is 0.54). As we expect an increase in borrowing is associated with larger number of new borrowing connections (number new lenders), while the increase in lending turns out to not affect significantly the number of new lending connections (number of new borrowers). We continue to include linear trend and now we also include country fixed effects ${ }^{24}$ In these regressions we have 72 countries for 29 years, an almost balanced panel with 1980 observations.

We find that local recessions lead to fewer new banks participating in the GBN. Both recessions

\footnotetext{
${ }^{24}$ Including instead time fixed effects precludes us from identifying effects of U.S. recessions and the global financial crisis. This alternative specification, however, strengthens our results with respect to local recessions and banking crises.
} 
and banking crises are associated with smaller average number of new lenders for the banks in the affected country - this is not surprising. While existing lenders are unlikely to exit during the crisis because they may not be interested in cashing in their losses, new investors are unlikely to enter a country immediately after a recession or a banking crisis. We also observe a large decline in the number of key banks overall in the aftermath of U.S. recessions, as well as an additional decline in the number of key banks in countries affected by local recessions. During the global financial crisis the number of key banks dropped in 2008, while in 2009 we observe a smaller number of borrowers per bank.

We repeat this country-level analysis separately for industrial and for developing countries and present the results in Table 3. The specification is identical to that of the bottom panel of Table 2. The top panel shows the results for 23 high income OECD countries, while the bottom panel presents the results for the remaining 49 countries in our regression sample.

We find no significant effects of recessions or crises on the new connections made by banks in the industrial countries. The only exception is a statistically significant decline in the average number of new borrowers of banks located in countries that experienced a banking crisis in the preceding year. We find a substantial decline in the number of key banks in industrial countries in the aftermath of U.S. recessions. Surprisingly, we find an increase in the number of key banks in industrial countries in 2009.

This indicates that our full sample results are likely to be driven by the banks from developing countries. Indeed, we find, as shown in the bottom panel of Table 3, local recessions and banking crises tend to lower the number of banks in these countries that enter the GBN and lower the number of new lenders of banks in the affected countries. We also observe a substantial and statistically significant decline in the number of banks entering the GBN during the global financial crisis. Local recessions and the global financial crisis are also associated with a reduction in the number of key banks in developing countries. Combined with the previous observation of an increase in 
the number of key banks in the industrial countries in 2009, this shows that global financial crisis moved the network center from developing to industrial countries.

Overall these results suggest that in the past 30 years network positions of banks in industrial countries have been quite resilient to the effects of recessions and banking crises, which cannot be said of banks in developing countries. Similarly, banks in the developing countries experienced more strongly the effects of the global financial crisis, which is consistent with a larger decline in international capital flows to and from these countries as documented in Milesi-Ferretti \& Tille (2011).

\subsection{Bank-level regressions}

Finally we turn to bank-level regressions where we study the effects of recessions and banking crises on the individual bank's probability of establishing a connection with a new lender or a new borrower or of becoming a key bank. We also investigate, conditional on establishing at least one new borrowing or lending connection, the effect of recessions and banking crises on the number of new connections made. The results are reported in Table 4. First three columns present the results of the linear probability model regressions of the probability of a new lender, new borrower, or becoming a key bank, while last two columns present negative binomial regressions for the number of new borrowing and lending connections, respectively. The reported regressions include country

fixed effects.25 All regressions include trend and continue to control for total borrowing and lending, this time by an individual bank in a given year.

In all regressions we also allow for the effects to be different for large banks. For the analysis of new borrowing connections, we label banks as "large" if their total borrowing over the entire sample is in the top $10 \%$ of that variable's distribution, excluding banks that did not borrow. Similarly,

\footnotetext{
${ }^{25}$ The results of linear probability regressions are almost identical if we include bank fixed effects instead, while including bank fixed effects in negative binomial regression is computationally challenging given the sample size.
} 
for the analysis of new lending connections, we label banks as "large" if their total lending over the entire sample is in the top $10 \%$ of the total lending distribution, excluding banks that did not lend. Finally, for the analysis of the probability of becoming a key bank, we label banks as "large" if they fall into larger lender and large borrower category. Using this approach, we code, out of 7526 banks in our sample 246 banks as large borrowers, 396 banks as large lenders and 60 banks as both large borrowers and large lenders. We interact our variables of interest with the "large bank" indicator, which itself has a positive and strongly significant effect, as we expected. Along with the coefficient and the standard error of the coefficients, we also report the P-value of the significance of the total effect for a large bank, based on the F-test for the linear probability regressions and on $\chi^{2}$-test for the NB regressions.

We find that the distribution of the impact of the global financial crisis was quite different from that of past local recessions and banking crises. Whereas in the aftermaths of recessions and banking crises small banks tend to be less likely to establish new connections, while large banks are resilient to these effects, during the global financial crisis large banks were much less likely to establish new connections than they normally would, while small banks were in fact more likely to find new borrowers. Similarly, large banks during the global financial crises were less likely to become key intermediaries, while small banks were not affected in that way. Both small and large banks that were able to find new borrowers and lenders during the crisis, established fewer new connections than they would otherwise.

The impact of U.S. recessions is also in contrast with that of the global financial crisis. In the year following a recession in the U.S. small banks are less likely to fined a new borrower and establish fewer relationships with new lenders, while large banks are in fact more likely to to obtain new borrowers, although those who do so, establish fewer connections with new borrowers. 


\section{Conclusion}

In this paper we introduced formal measures to describe bank relationships in the global banking network. Using loan-level data, we constructed networks for each of the years between 1980 and 2009 and computed network statistics for each of the banks that appeared as either a borrower or a lender in the syndicated loan market during our sample period.

We find that recessions and banking crises have an important systematic effect on the development of the global banking network through altering the ways in which banks make new connections. Global financial crisis in particular played an important role by shifting the center of network from developing to developed countries and by affecting the formation of new relationships by large banks, banks that are normally immune to the effects of local recessions and banking crises.

Our findings have two important implications. A methodological implication is that the structure of a global banking network responds to economic and financial shocks, and it may therefore not be appropriate to model banking networks as static and exogenous in a dynamic setting, especially when the effects of financial shocks are analyzed. A broad empirical implication is that inasmuch as bank relationships facilitate international capital flows by overcoming information asymmetry obstacles, the slow down in building bank relationships during recessions and banking crises, and especially during the global financial crisis, might be important in understanding the patterns of international capital flows in the aftermath of such events. 


\section{References}

Ahearne, A. G., Griever, W. L., \& Warnock, F. E. (2004). Information costs and home bias: an analysis of us holdings of foreign equities. Journal of International Economics, 62(2), 313-336.

Allen, F. \& Gale, D. (2000). Financial contagion. Journal of Political Economy, 108, 1-33.

Bae, K.-H., Stulz, R. M., \& Tan, H. (2008). Do local analysts know more? a cross-country study of the performance of local analysts and foreign analysts. Journal of Financial Economics, 88(3), 581-606.

Battiston, S., Delli Gatti, D., Gallegati, M., Greenwald, B. C., \& Stiglitz, J. E. (2009). Liaisons dangereuses: Increasing connectivity, risk sharing, and systemic risk. NBER Working Paper 15611.

Boot, A. W. (2000). Relationship banking: What do we know? Journal of Financial Intermediation, 9, 7-25.

Bottazzi, L., Da Rin, M., \& Hellmann, T. (2009). The importance of trust for investment: Evidence from venture capital. CentER Discussioin Paper No. 2009-43, Tilburg University.

Brennan, M. J. \& Cao, H. H. (1997). International portfolio investment flows. Journal of Financial Economics, 52(5), 1851-80.

Caballero, J., Candelaria, C., \& Hale, G. (2009). Bank relationships and the depth of the current economic crisis. Economic Letter December 14, FRBSF.

Castiglionesi, F. \& Navarro, N. (2007). Optimal fragile financial networks. Tilburg University Center for Economic Research Discussion Paper 2007-100.

Chan, K., Menkveld, A. J., \& Yang, Z. (2008). Information asymmetry and asset prices: Evidence from the china foreign share discount. Journal of Finance, 63(1), 159-196.

Chan-Lau, J., Espinosa-Vega, M. A., Giesecke, K., \& Solé, J. (2009). Assessing the Systemic Implications of Financial Linkages, volume April, chapter 2. International Monetary Fund.

Cocco, J. a. F., Gomes, F. J., \& Martins, N. C. (2009). Lending relationships in the interbank market. Journal of Financial Intermediation, 18, 24-48.

Coval, J. \& Moscowitz, T. (2001). The geography of investment: Informed trading and asset prices. Journal of Political Economy, 109, 811-41.

Craig, B. \& von Peter, G. (2010). Interbank tiering and money center banks. BIS Working Paper 322.

Delli Gatti, D., Gallegati, M., Greenwald, B., Russo, A., \& Stiglitz, J. E. (2010). The financial accelerator in an evolving credit network. Journal of Economic Dynamics and Control, $34(9)$, $1627-50$. 
Fratzscher, M. (2011). Capital flows, global shocks and the 2007-08 financial crisis. Unpublished manuscript.

Garratt, R., Mahadeva, L., \& Svirydzenka, K. (2011). Mapping systemic risk in the international banking network. Bank of England Working Paper 413.

Guiso, L., Sapienza, P., \& Zingales, L. (2009). Cultural biases in economic exchange. Quarterly Journal of Economics.

Haldane, A. G. (2009). Rethinking the financial network.

Haldane, A. G. \& May, R. M. (2011). Systemic risk in banking ecosystems. Nature, 469, 351-355.

Hale, G., Candelaria, C., Caballero, J., \& Borisov, S. (2011). Global banking network and international capital flows. Unpublished manuscript.

Hatchondo, J. C. (2008). Asymmetric information and the lack of international portfolio diversification. International Economic Review, 49(4), 1297-1330.

Huberman, G. (2001). Familiarity breeds investment. Review of Financial Studies, 14, 659-80.

Ivashina, V. \& Scharfstein, D. (2010). Loan syndication and credit cycles. American Economic Review, 100, 57-61.

Kang, J.-K. \& Stulz, R. M. (1997). Why is there a home bias? an analysis of foreign portfolio equity ownership in japan. Journal of Financial Economics, 46(1), 3-28.

Karlan, D., Mobious, M., Rosenblat, T., \& Szeidl, A. (2009). Trust and social collateral. Quarterly Journal of Economics.

Kubelec, C. \& Sá, F. (2010). The geographical composition of national external balance sheets: 1980-2005. Bank of England Working Paper 384.

Laeven, L. \& Valencia, F. (2008). Systemic banking crises: A new database. IMF working paper 08/224, International Monetary Fund.

Lehmann, E. \& Neuberger, D. (2001). Do lending relationships matter? evidence from bank survey data in germany. Journal of Economic Behavior and Organization.

May, R. M. \& Arinaminpathy, N. (2010). Systemic risk: the dynamics of model banking systems. Journal of the Royal Society Interface, 7, 823-838.

Mian, A. (2006). Distance constraints: The limits of foreign lending in poor economies. Journal of Finance, 61, 1005-56.

Milesi-Ferretti, G. M. \& Tille, C. (2011). The great retrenchment: Internatiional capital flows during the global financial crisis. Economic Policy, 26 (66), 289-346. 
Minoiu, C. \& Reyes, J. A. (2011). A network analysis of global banking: 1978-2009. IMF Working Paper $11 / 74$.

Mirchev, L., Slavova, V., \& Elefteridis, H. (2010). Financial system transformation: A network approach. Working Paper.

Miura, H. (2010). Network sgl: Stata graph library for network analysis. Technical report, Federal Reserve Bank of San Francisco, San Francisco, CA. under review by the Stata Journal.

Moulton, B. R. (1990). An illustration of a pitfall in estimating the effects of aggregate variables on micro units. The Review of Economics and Statistics, 72(2), 334-338.

Nier, E., Yang, J., Yorulmazer, T., \& Alentorn, A. (2007). Network models and financial stability. Journal of Economic Dynamics and Control, 31(6), 2033-60.

Okawa, Y. \& Van Wincoop, E. (2010). Gravity in international finance. HKIMR Working Paper No. $07 / 2010$.

Peek, J. \& Rosengren, E. (2000). Collater damage: Effects of the japanese bank crisis on real activity in the united states. American Economic Review, 90, 30-45.

Pilloff, S. J. (2004). Bank merger activity in the united state, 1994-2003. Federal Reserve Board of Governors Staff Study 176.

Portes, R. \& Rey, H. (2005). The determinants of cross-border equity flows. Journal of International Economics, 65(2), 269296.

Portes, R., Rey, H., \& Oh, Y. (2001). Information and capital flows: the determinants of transactions in financial assets. European Economic Review, 45(4), 783796.

Putnam, R. (1995). Bowling alone: America's declining social capital. Journal of Domocracy.

Reinhart, C. M. \& Rogoff, K. S. (2009). The aftermath of financial crises. Paper prepared for presentation at the American Economic Association meetings in San Francisco.

Rose, A. \& Wieladek, T. (2011). Financial protectionism: The first tests. NBER WP 17073.

Rose, A. K. \& Spiegel, M. M. (2007). Offshore financial centres: Parasites or symbionts? The Economic Journal, 117(523), 1310-1335.

Sachs, A. (2010). Completeness, interconnectedness and distribution of interbank exposures a parameterized analysis of the stability of financial networks. Deutsche Bundesbank Duscussion Paper 08/2010.

Schularick, M. \& Taylor, A. M. (2010). Credit booms gone bust: Monetary policy, leverage cycles and financial crises, 1980-2008. Paper presented at the FRBSF conference on Monetary Economics. 
Veldcamp, L. \& Van Nieuwerburgh, S. (2009). Information immobility and the home bias puzzle. Journal of Finance, 64, 1187-1215.

von Peter, G. (2007). International banking centres: a network perspective. BIS Quarterly Review. 


\section{Appendix}

Here we show the conditions for our full model equilibrium to be stable and for the interior equilibrium, that is $0<\alpha^{*}<1$ and $0<\nu<1$, and the derive comparative statics discussed in the text. Remember that equilibrium is described in the short run by equations (4)-(5) given $\gamma$.

Let $\xi=R^{*-1}\left(\frac{F+\phi \bar{R}-V}{\phi^{*}}\right)$ with $\partial R^{*-1}(x) / \partial x=G<0$. Recall that

$$
\Psi=\alpha^{*}\left(N^{*}-\gamma N\right)+(2 \gamma+\nu) N
$$

Thus, we can rewrite (4) as

$$
\alpha^{*}=\frac{\xi-2 \gamma N}{N^{*}-\gamma N}-\frac{N}{N^{*}-\gamma N} \nu
$$

Substituting (4) into (5) and rearranging, we get

$$
\alpha^{*}=1-\frac{N}{\left(N^{*}-\gamma N\right) y} \nu,
$$

where $y=\left(F+\phi \bar{R}-V-D^{*}\right) / F$.

We can solve these two equations to obtain the short-run solution

$$
\begin{gathered}
\alpha^{* S R}=\frac{y\left(N^{*}-\gamma N\right)-(\xi-2 \gamma N)}{\left(N^{*}-\gamma N\right)(y-1)}, \\
\nu^{S R}=\frac{y\left(\xi-\gamma N-N^{*}\right.}{N(y-1)} .
\end{gathered}
$$

One can show graphically that the equilibrium is stable if $(7)$ is steeper than $(8)$, that is $y>1$, which means that $\phi \bar{R}-V-D^{*}>0$. We can also simply show that both $0<\alpha *<1$ and $0<\nu<1$ if the following binding conditions hold:

$$
\begin{gathered}
\xi>N^{*}+\gamma N, \\
y-1>\frac{\xi-\left(N^{*}+\gamma N\right)}{N^{*}-\gamma N}>0 .
\end{gathered}
$$

We can also derive

$$
\frac{\partial \nu^{S R}}{\partial \gamma}=-\frac{y}{y-1}<0
$$

since $y>1$ is required for stability of the equilibrium and for interior solution.

In the long run, (6) has to also hold, which implies that

$$
\gamma=\frac{\phi^{*}}{1-\phi^{*}} \nu .
$$


Note that $\gamma$ is not a function of $\alpha^{*}$. Thus, we can simply substitute (11) into (10) to obtain

$$
\nu^{L R}=\frac{y\left(\xi-N^{*}\right)\left(1-\phi^{*}\right)}{N\left(y-1+\phi^{*}\right)} .
$$

We now derive comparative statics for $\nu^{S R}$ and $\nu^{S R}$ with respect to parameters of the model. We have already shown that $\partial \nu^{S R} / \partial \gamma<0$. The rest follow:

$$
\begin{aligned}
\frac{\partial \nu^{S R}}{\partial \phi^{*}} & =\frac{1}{N(y-1)^{2}\left(1-\phi^{*}\right)}\left[\frac{(F-f)\left(\xi-\gamma N-N^{*}\right.}{F\left(1-\phi^{*}\right)}-G \frac{y(y-1)\left(F+\phi \bar{R}-(2 F+\phi \bar{R}-f) \phi^{* 2}\right.}{\phi^{* 2}\left(1-\phi^{*}\right)}\right]>0 \\
\frac{\partial \nu^{L R}}{\partial \phi^{*}} & =\frac{1}{N\left(y-1+\phi^{*}\right)^{2}}\left[(\xi-N)\left(1-\frac{f}{F}-y^{2}\right)-G \frac{\left(y-1+\phi^{*}\right)\left(F+\phi \bar{R}-(2 F+\phi \bar{R}-f) \phi^{* 2}\right.}{\phi^{* 2}\left(1-\phi^{*}\right)}\right]
\end{aligned}
$$

which is ambiguous because the first term in the brackets is negative given $y>1$ and the second term is positive given $G<0$. The difference between the effects on $\nu^{S R}$ and $\nu^{L R}$ is the adjustment of $\gamma$. We will assume that these effects are second-order and therefore overall effect of $\phi^{*}$ on the number of new connections made is positive. We will make a similar assumption in similar cases in what follows.

If there is an increase in returns on foreign project for any number of projects financed (an upward shift in $R^{*}$ ), this also implies an increase in $\xi$ for given level of other parameter values. It follows that such an increase in $R^{*}$ will increase $\nu$ both in short and in long run, because

$$
\frac{\partial \nu^{S R}}{\partial \xi}=\frac{y}{N(y-1)}>0, \quad \frac{\partial \nu^{L R}}{\partial \xi}=\frac{y\left(1-\phi^{*}\right)}{N\left(y-1+\phi^{*}\right)} .
$$

Since $\phi$ and $\bar{R}$ always enter together, their effects will be the same, hence we simply take derivative with respect to their product $\phi \bar{R}$ :

$$
\begin{gathered}
\frac{\partial \nu^{S R}}{\partial(\phi \bar{R})}=-\frac{1}{N(y-1)^{2}}\left[\frac{\xi-\gamma N-N^{*}}{F}-G \frac{y(y-1)}{\phi^{*}}\right]<0, \\
\frac{\partial \nu^{L R}}{\partial(\phi \bar{R})}=-\frac{1}{N\left(y-1+\phi^{*}\right)^{2}}\left[\frac{\xi-N^{*}}{F}-G \frac{y\left(y-1+\phi^{*}\right)}{\phi^{*}\left(1-\phi^{*}\right)}\right]<0 .
\end{gathered}
$$

Next,

$$
\begin{gathered}
\frac{\partial \nu^{S R}}{\partial D^{*}}=\frac{\xi-\gamma N-N^{*}}{F N(y-1)^{2}}>0, \\
\frac{\partial \nu^{L R}}{\partial D^{*}}=\frac{\left(\xi-N^{*}\right)\left(1-\phi^{*}\right)^{2}}{F N\left(y-1+\phi^{*}\right)^{2}}>0 .
\end{gathered}
$$

The fee for establishing a new connection $F$ has two effects - it increases a cost of establishing 
a new connection, but it also increases the value of relationship if $f$ remains constant. Since we want to disentangle these two effects, we will examine separately an increase in fee for a new connection holding the value of relationship $V$ constant (that is, an increase in $F$ and $f$ of equal magnitude), and a decline in the value of relationship holding fee for a new connection constant (that is, and increase in $f$ holding $F$ constant).

$$
\begin{gathered}
\left.\frac{\partial \nu^{S R}}{\partial F}\right|_{V=\text { const. }}=\frac{1}{N(y-1)^{2}}\left[\frac{\left(\phi \bar{R}-D^{*}-V\right)\left(\xi-\gamma N-N^{*}\right.}{F^{2}}+G \frac{y(y-1)}{\phi^{*}}\right], \\
\left.\frac{\partial \nu^{L R}}{\partial F}\right|_{V=\text { const. }}=\frac{1}{N\left(y-1+\phi^{*}\right)^{2}}\left[\frac{\left(\phi \bar{R}-D^{*}-V\right)\left(\xi-N^{*}\right.}{F^{2}}+G \frac{y\left(y-1+\phi^{*}\right)}{\phi^{*}\left(1-\phi^{*}\right)}\right],
\end{gathered}
$$

which are both ambiguous unless we want to make assumptions on the shape of $R^{*}$ function. There are two opposing effects at play — when $F$ increases, home banks are less interested in financing foreign projects, while foreign banks are also less interested in financing their projects because return on intermediation increases. Finally,

$$
\begin{gathered}
\frac{\partial \nu^{S R}}{\partial f}=-\frac{1}{N(y-1)^{2}}\left[\frac{\phi^{*}\left(\xi-\gamma N-N^{*}\right.}{F\left(1-\phi^{*}\right)}-G \frac{y(y-1)}{\left(1-\phi^{*}\right)}\right]<0, \\
\frac{\partial \nu^{L R}}{\partial f}=-\frac{1}{N\left(y-1+\phi^{*}\right)}\left[\frac{\phi^{*}\left(\xi-N^{*}\right.}{F}-G \frac{y\left(y-1+\phi^{*}\right)}{1-\phi^{*}}\right]<0 .
\end{gathered}
$$


Figure 1: Relevance of the syndicated bank loan market

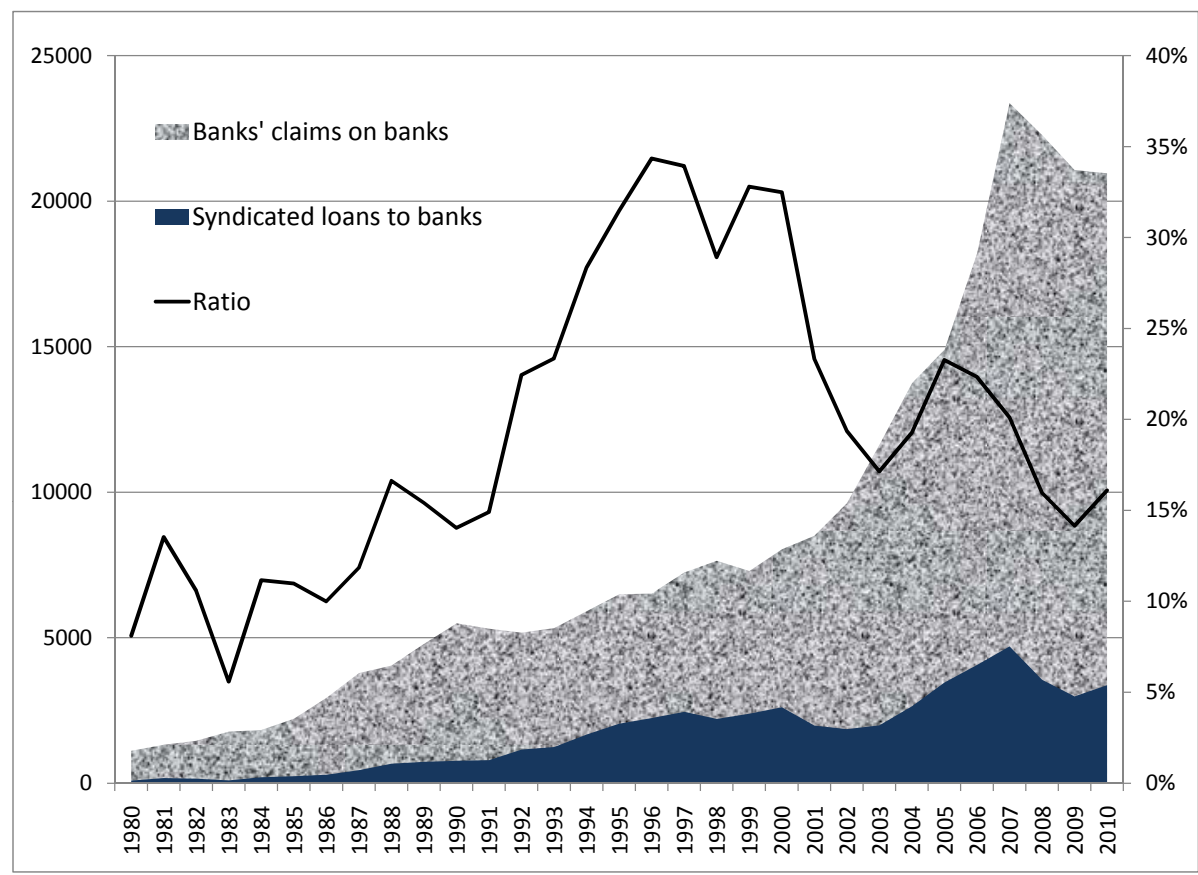


Figure 2: Network size
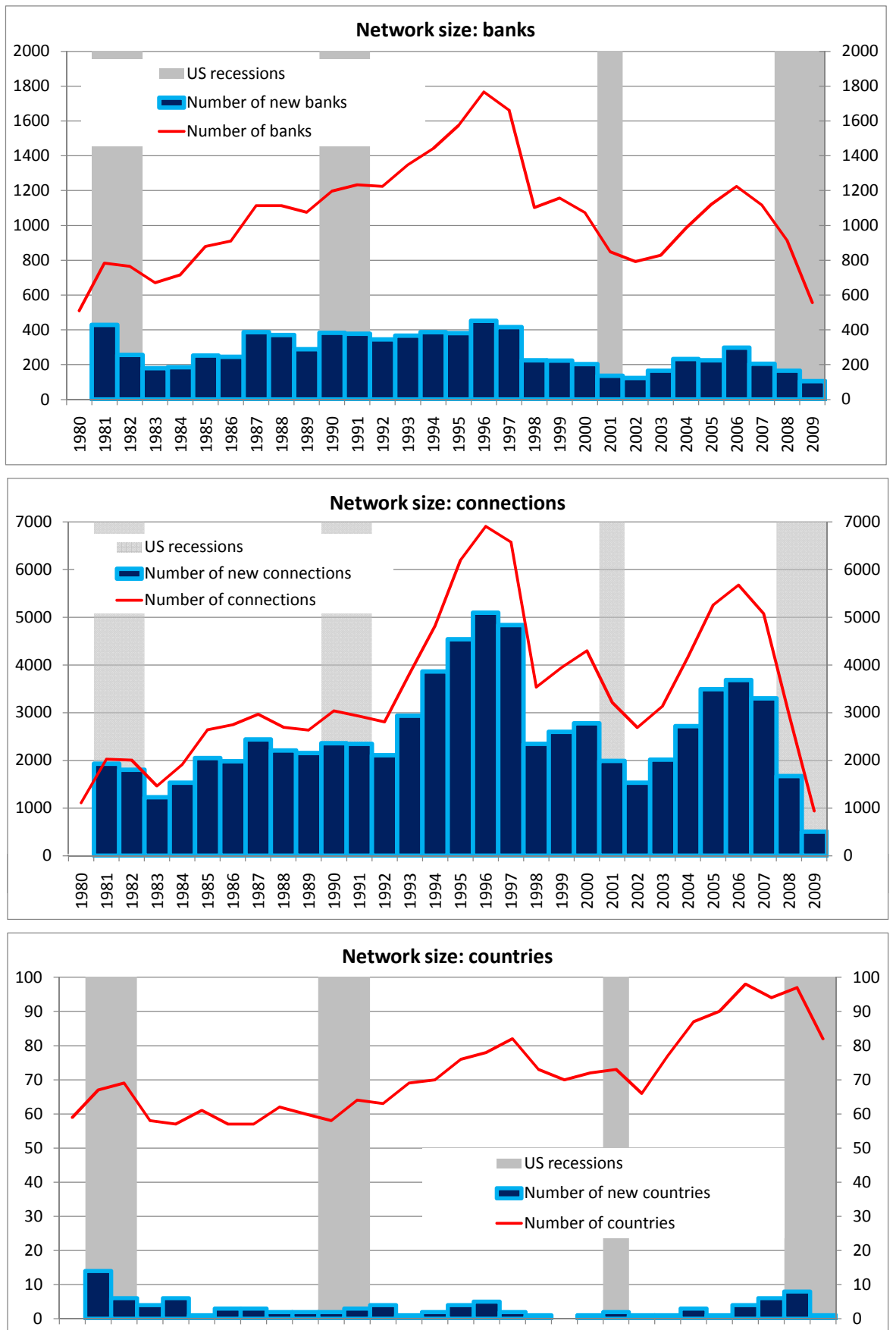

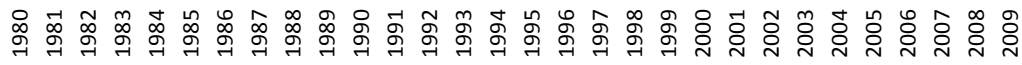


Figure 3: Network connectivity
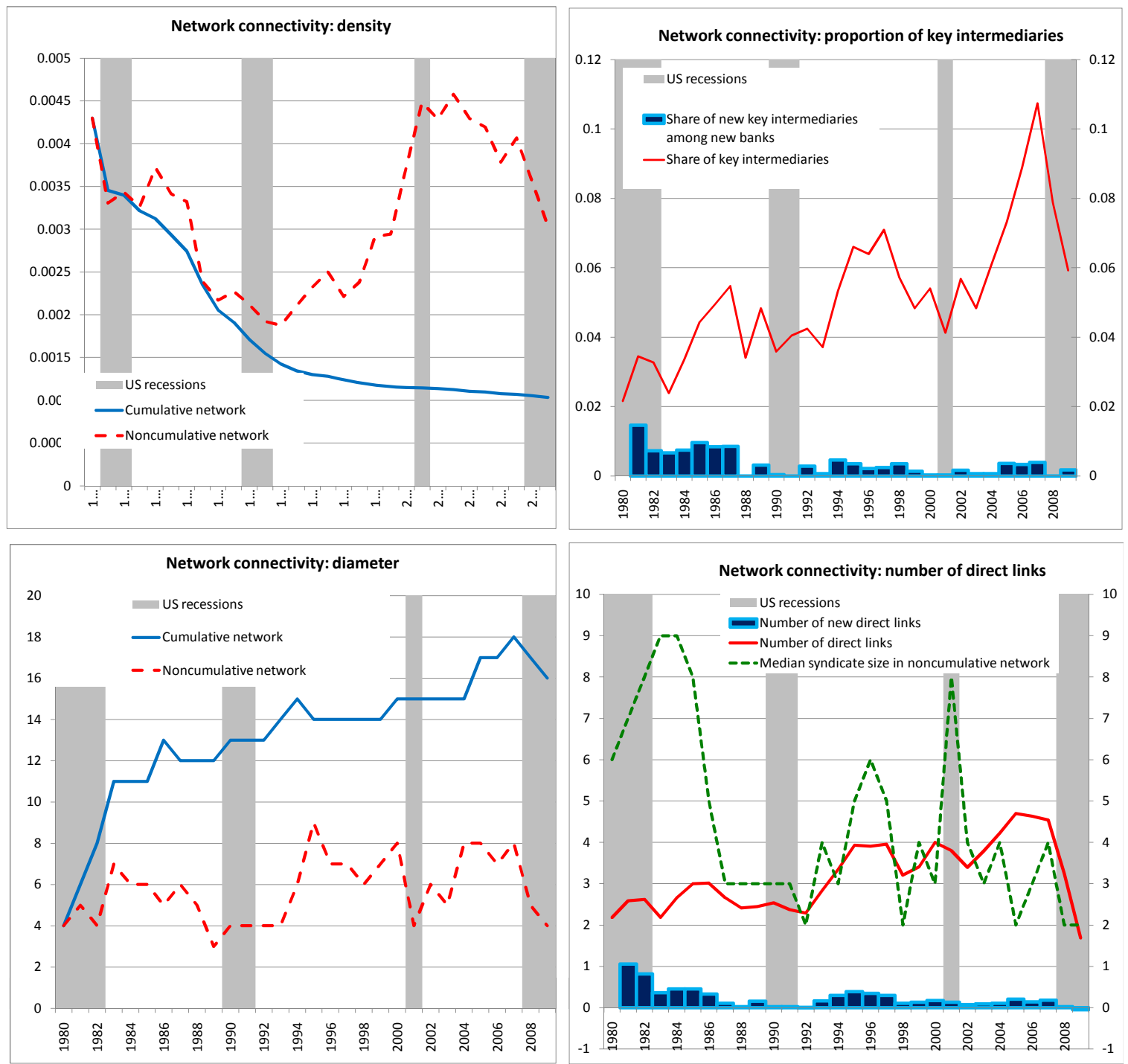
Table 1: New relationships, key banks, borrowing, and lending

\begin{tabular}{lcccc}
\hline \hline Dependant var. & $\begin{array}{c}(1) \\
\text { Borrowing } \\
\text { Regression level }\end{array}$ & $\begin{array}{c}(2) \\
\text { Lending } \\
\text { Bank }\end{array}$ & $\begin{array}{c}(3) \\
\text { Borrowing } \\
\text { Country }\end{array}$ & $\begin{array}{c}(4) \\
\text { Lending } \\
\text { Country }\end{array}$ \\
\hline Regressor: & I(New lender) & I(New borrower) & \# Key banks & \# Key banks \\
contemp. & $598.722^{a}$ & $168.001^{a}$ & $0.602^{b}$ & $1.188^{b}$ \\
& $(34.572)$ & $(11.595)$ & $(0.268)$ & $(0.535)$ \\
L1 & $29.043^{c}$ & $54.761^{a}$ & $0.818^{a}$ & $0.727^{c}$ \\
& $(17.460)$ & $(10.276)$ & $(0.268)$ & $(0.433)$ \\
L2 & -4.409 & $39.203^{a}$ & $0.714^{a}$ & 0.688 \\
& $(12.374)$ & $(8.364)$ & $(0.276)$ & $(0.487)$ \\
L3 & $26.636^{c}$ & 15.922 & $0.692^{a}$ & $1.304^{c}$ \\
& $(13.761)$ & $(9.863)$ & $(0.235)$ & $(0.735)$ \\
L4 & 1.179 & 6.039 & $0.362^{c}$ & $1.701^{b}$ \\
& $(5.201)$ & $(7.010)$ & $(0.187)$ & $(0.730)$ \\
Controls : & & & & \\
Trend & $-0.484^{a}$ & $0.691^{b}$ & -0.007 & -0.030 \\
& $(0.178)$ & $(0.282)$ & $(0.011)$ & $(0.023)$ \\
Fixed effects & Bank & Bank & Country & Country \\
Observations & 100973 & 100973 & 1764 & 1764 \\
Banks & 6982 & 6982 & & \\
Countries & 72 & 72 & 72 & 72 \\
Adjusted $R^{2}$ & 0.161 & 0.245 & 0.568 & 0.546 \\
\hline \hline
\end{tabular}

OLS regressions with fixed effects as indicated.

Robust standard errors in parenthesis.

${ }^{a}$ significant at $1 \%$ level; ${ }^{b}$ significant at $5 \%$ level; ${ }^{c}$ significant at $10 \%$ level. 
Table 2: Effects of recession and banking crises on network characteristics

\begin{tabular}{|c|c|c|c|c|c|}
\hline Dependent var.: & $\begin{array}{c}(1) \\
\text { \# New Banks }\end{array}$ & $\begin{array}{c}(2) \\
\text { \# New Lenders }\end{array}$ & $\begin{array}{c}(3) \\
\# \text { New Borrowers }\end{array}$ & (4) & $\begin{array}{c}(5) \\
\# \text { New Key banks }\end{array}$ \\
\hline \multicolumn{6}{|c|}{ Time series regressions } \\
\hline \multirow[t]{2}{*}{ L.I(US recession) } & 13.833 & 0.326 & 0.266 & -1.904 & -0.114 \\
\hline & $(33.247)$ & $(0.293)$ & $(0.249)$ & $(3.103)$ & $(0.097)$ \\
\hline \multirow[t]{2}{*}{ L.\# Recessions } & -0.950 & -0.010 & $-0.011^{c}$ & $-0.286^{c}$ & $-0.009^{b}$ \\
\hline & $(1.137)$ & $(0.006)$ & $(0.005)$ & $(0.161)$ & $(0.004)$ \\
\hline \multirow[t]{2}{*}{ L.\# Banking crises } & -16.998 & -0.030 & $-0.053^{c}$ & -1.657 & $-0.058^{b}$ \\
\hline & $(9.917)$ & $(0.032)$ & $(0.030)$ & $(1.133)$ & $(0.028)$ \\
\hline \multirow[t]{2}{*}{$\mathrm{I}($ Year=2008) } & -9.790 & 0.006 & 0.037 & $-18.515^{a}$ & $-0.780^{a}$ \\
\hline & $(36.040)$ & $(0.104)$ & $(0.108)$ & $(6.228)$ & $(0.147)$ \\
\hline \multirow[t]{2}{*}{$\mathrm{I}($ Year=2009) } & -17.692 & -0.039 & 0.072 & 5.714 & 0.229 \\
\hline & $(48.925)$ & $(0.196)$ & $(0.188)$ & $(5.567)$ & $(0.173)$ \\
\hline$\Delta$ borrowing & $1134.5^{a}$ & 0.009 & 0.480 & $133.1^{a}$ & $4.366^{a}$ \\
\hline Trend & $-8.531^{a}$ & $-0.041^{a}$ & $-0.054^{a}$ & -0.068 & -0.001 \\
\hline Observations & 29 & 29 & 29 & 29 & 29 \\
\hline Adjusted $R^{2}$ & 0.558 & 0.488 & 0.652 & 0.606 & $\alpha: 0.01$ \\
\hline \multicolumn{6}{|c|}{ Country panel regressions } \\
\hline \multirow[t]{2}{*}{ L.I(US recession) } & -0.372 & -0.027 & 0.046 & $-0.109^{b}$ & $-0.246^{b}$ \\
\hline & $(0.298)$ & $(0.203)$ & $(0.045)$ & $(0.047)$ & $(0.120)$ \\
\hline \multirow[t]{2}{*}{ L.I(Recession) } & $-0.537^{b}$ & $-0.626^{a}$ & -0.039 & $-0.090^{b}$ & $-0.256^{a}$ \\
\hline & $(0.216)$ & $(0.133)$ & $(0.030)$ & $(0.038)$ & $(0.089)$ \\
\hline \multirow[t]{2}{*}{ L.I(Banking crisis) } & -1.019 & $-0.511^{c}$ & -0.068 & 0.003 & 0.121 \\
\hline & $(0.774)$ & $(0.305)$ & $(0.092)$ & $(0.078)$ & $(0.291)$ \\
\hline \multirow[t]{2}{*}{$\mathrm{I}($ Year $=2008)$} & $-0.907^{c}$ & -0.123 & -0.084 & $-0.297^{a}$ & $-0.968^{a}$ \\
\hline & $(0.512)$ & $(0.182)$ & $(0.051)$ & $(0.082)$ & $(0.291)$ \\
\hline \multirow[t]{2}{*}{$\mathrm{I}($ Year=2009) } & -0.670 & 0.099 & $-0.229^{a}$ & 0.009 & 0.039 \\
\hline & $(0.639)$ & $(0.273)$ & $(0.068)$ & $(0.110)$ & $(0.284)$ \\
\hline$\Delta$ borrowing & $264.769^{a}$ & $41.158^{a}$ & $-7.130^{b}$ & $38.547^{a}$ & $20.921^{a}$ \\
\hline$\Delta$ lending & 16.018 & $-8.744^{a}$ & 1.448 & $13.154^{b}$ & $3.098^{c}$ \\
\hline Trend & $-0.089^{a}$ & $-0.073^{a}$ & $-0.018^{a}$ & 0.003 & $0.014^{b}$ \\
\hline Fixed effects & Country & Country & Country & Country & Country \\
\hline Observations & 1980 & 1980 & 1980 & 1980 & 1980 \\
\hline Countries & 72 & 72 & 72 & 72 & 72 \\
\hline Adjusted $R^{2}$ & 0.657 & 0.176 & 0.359 & 0.369 & $\alpha: 0.48^{a}$ \\
\hline
\end{tabular}

OLS regressions in (1)-(4). Negative binomial (NB) regressions in column (5) .

Dispersion parameter in NB regressions is $1+\alpha e^{X^{\prime} \beta}$, where $\alpha$ is estimated. $\alpha=0$ corresponds to Poisson regression. NB estimated by ML.

Robust standard errors in parenthesis. ${ }^{a}$ significant at $1 \%$ level; ${ }^{b}$ significant at $5 \%$ level; ${ }^{c}$ significant at $10 \%$ level. 
Table 3: Industrial and developing countries

\begin{tabular}{|c|c|c|c|c|c|}
\hline & $(1)$ & $(2)$ & $(3)$ & (4) & $(5)$ \\
\hline Dependent var.: & \# New Banks & \# New Lenders & \# New Borrowers & & \# New Key banks \\
\hline \multicolumn{6}{|c|}{ High income OECD countries } \\
\hline \multirow[t]{2}{*}{ L.I(US recession) } & -0.670 & -0.103 & -0.011 & $-0.250^{a}$ & $-0.425^{a}$ \\
\hline & $(0.733)$ & $(0.115)$ & $(0.077)$ & $(0.094)$ & $(0.161)$ \\
\hline \multirow[t]{2}{*}{ L.I(Recession) } & -0.742 & -0.078 & -0.057 & -0.114 & -0.154 \\
\hline & $(0.517)$ & $(0.095)$ & $(0.052)$ & $(0.074)$ & $(0.117)$ \\
\hline \multirow[t]{2}{*}{ L.I(Banking crisis) } & -3.774 & 0.017 & $-0.440^{a}$ & -0.155 & 0.062 \\
\hline & $(5.414)$ & $(0.151)$ & $(0.138)$ & $(0.182)$ & $(0.246)$ \\
\hline \multirow[t]{2}{*}{$\mathrm{I}($ Year=2008) } & -0.240 & -0.086 & -0.027 & -0.132 & -0.413 \\
\hline & $(1.068)$ & $(0.123)$ & $(0.085)$ & $(0.125)$ & $(0.309)$ \\
\hline \multirow[t]{2}{*}{$\mathrm{I}($ Year=2009) } & -0.139 & 0.089 & -0.167 & $0.447^{c}$ & $0.673^{c}$ \\
\hline & $(1.590)$ & $(0.146)$ & $(0.116)$ & $(0.228)$ & $(0.365)$ \\
\hline$\Delta$ borrowing & $249.900^{a}$ & $5.550^{b}$ & $-10.473^{a}$ & $33.775^{b}$ & $17.101^{a}$ \\
\hline$\Delta$ lending & 15.833 & -1.504 & 1.848 & $12.974^{b}$ & $3.935^{b}$ \\
\hline Trend & $-0.242^{a}$ & $-0.030^{a}$ & $-0.036^{a}$ & $-0.012^{b}$ & $-0.014^{c}$ \\
\hline Observations & 665 & 665 & 665 & 665 & 665 \\
\hline Countries & 23 & 23 & 23 & 23 & 23 \\
\hline Adjusted $R^{2}$ & 0.685 & 0.227 & 0.382 & 0.385 & $\alpha: 0.18^{a}$ \\
\hline \multicolumn{6}{|l|}{ Other countries } \\
\hline \multirow[t]{2}{*}{ L.I(US recession) } & -0.128 & -0.035 & $0.083^{c}$ & -0.008 & 0.044 \\
\hline & $(0.216)$ & $(0.298)$ & $(0.054)$ & $(0.047)$ & $(0.184)$ \\
\hline \multirow[t]{2}{*}{ L.I(Recession) } & $-0.616^{a}$ & $-0.790^{a}$ & -0.046 & $-0.093^{b}$ & $-0.387^{a}$ \\
\hline & $(0.177)$ & $(0.181)$ & $(0.037)$ & $(0.043)$ & $(0.141)$ \\
\hline \multirow[t]{2}{*}{ L.I(Banking crisis) } & -0.315 & $-0.631^{c}$ & 0.023 & 0.034 & 0.218 \\
\hline & $(0.270)$ & $(0.327)$ & $(0.102)$ & $(0.083)$ & $(0.398)$ \\
\hline \multirow[t]{2}{*}{$\mathrm{I}($ Year=2008) } & $-1.219^{b}$ & -0.315 & -0.116 & $-0.383^{a}$ & $-1.593^{a}$ \\
\hline & $(0.433)$ & $(0.320)$ & $(0.061)$ & $(0.105)$ & $(0.607)$ \\
\hline \multirow[t]{2}{*}{$\mathrm{I}($ Year=2009) } & $-1.051^{b}$ & 0.093 & $-0.271^{a}$ & $-0.234^{b}$ & $-0.737^{c}$ \\
\hline & $(0.446)$ & $(0.387)$ & $(0.078)$ & $(0.104)$ & $(0.422)$ \\
\hline$\Delta$ borrowing & 134.362 & $465.905^{a}$ & 2.751 & 21.854 & $48.651^{c}$ \\
\hline$\Delta$ lending & $1670.626^{a}$ & $-500.336^{a}$ & $129.965^{a}$ & $402.490^{a}$ & $158.643^{b}$ \\
\hline Trend & -0.010 & $-0.100^{a}$ & $-0.009^{a}$ & $0.009^{a}$ & $0.046^{a}$ \\
\hline Observations & 1315 & 1315 & 1315 & 1315 & 1315 \\
\hline Countries & 49 & 49 & 49 & 49 & 49 \\
\hline Adjusted $R^{2}$ & 0.526 & 0.184 & 0.323 & 0.393 & $\alpha: 0.81^{a}$ \\
\hline
\end{tabular}

OLS regressions with country fixed effects in (1)-(4). Negative binomial (NB) regressions in column (5) .

Dispersion parameter in NB regressions is $1+\alpha e^{X^{\prime} \beta}$, where $\alpha$ is estimated. $\alpha=0$ corresponds to Poisson regression. NB estimated by ML.

Robust standard errors in parenthesis. ${ }^{a}$ significant at $1 \%$ level; ${ }^{b}$ significant at $5 \%$ level; ${ }^{c}$ significant at $10 \%$ level. 
Table 4: Small and large banks

\begin{tabular}{|c|c|c|c|c|c|}
\hline & $(1)$ & $(2)$ & $(3)$ & $(4)$ & $(5)$ \\
\hline Dependent var.: & I(New lender) & I(New borrower) & I(become key) & \# New lenders & \# New borrowers \\
\hline \multirow[t]{2}{*}{ L.I(US recession) } & -0.004 & $-0.013^{b}$ & -0.001 & $-0.135^{b}$ & -0.033 \\
\hline & $(0.003)$ & $(0.006)$ & $(0.001)$ & $(0.069)$ & $(0.048)$ \\
\hline \multirow[t]{3}{*}{ * Large bank } & 0.013 & $0.059^{b}$ & -0.015 & 0.125 & $-0.287^{a}$ \\
\hline & $(0.016)$ & $(0.027)$ & $(0.010)$ & $(0.110)$ & $(0.045)$ \\
\hline & {$[0.59]$} & {$[0.099]^{c}$} & {$[0.13]$} & {$[0.91]$} & {$[0.00]^{a}$} \\
\hline \multirow[t]{2}{*}{ L.I(Recession) } & $-0.009^{b}$ & $-0.014^{c}$ & $-0.002^{b}$ & -0.007 & -0.028 \\
\hline & $(0.004)$ & $(0.008)$ & $(0.001)$ & $(0.044)$ & $(0.052)$ \\
\hline \multirow[t]{3}{*}{ * Large bank } & 0.009 & 0.040 & 0.011 & -0.022 & $0.080^{c}$ \\
\hline & $(0.017)$ & $(0.036)$ & $(0.010)$ & $(0.067)$ & $(0.048)$ \\
\hline & {$[0.97]$} & {$[0.45]$} & {$[0.37]$} & {$[0.71]$} & {$[0.15]$} \\
\hline \multirow[t]{2}{*}{ L.I(Banking crisis) } & -0.005 & $-0.019^{c}$ & 0.002 & -0.118 & -0.056 \\
\hline & $(0.007)$ & $(0.011)$ & $(0.001)$ & $(0.179)$ & $(0.106)$ \\
\hline \multirow[t]{3}{*}{ * Large bank } & -0.004 & -0.013 & $-0.034^{b}$ & 0.294 & -0.004 \\
\hline & $(0.031)$ & $(0.046)$ & $(0.016)$ & $(0.208)$ & $(0.138)$ \\
\hline & {$[0.76]$} & {$[0.53]$} & {$[0.044]^{b}$} & {$[0.27]$} & {$[0.60]$} \\
\hline \multirow[t]{2}{*}{$\mathrm{I}($ Year $=2008)$} & 0.003 & $0.043^{a}$ & -0.001 & $-0.415^{a}$ & $-0.185^{c}$ \\
\hline & $(0.004)$ & $(0.009)$ & $(0.001)$ & $(0.117)$ & $(0.097)$ \\
\hline \multirow[t]{3}{*}{ * Large bank } & $-0.048^{b}$ & $-0.212^{a}$ & -0.010 & -0.026 & $-0.247^{c}$ \\
\hline & $(0.024)$ & $(0.033)$ & $(0.007)$ & $(0.266)$ & $(0.135)$ \\
\hline & {$[0.056]^{c}$} & {$[0.00]^{a}$} & {$[0.091]^{c}$} & {$[0.082]^{c}$} & {$[0.00]^{a}$} \\
\hline \multirow[t]{2}{*}{$\mathrm{I}($ Year=2009) } & 0.007 & $0.046^{a}$ & $0.003^{b}$ & $-1.036^{a}$ & $-0.794^{a}$ \\
\hline & $(0.006)$ & $(0.014)$ & $(0.001)$ & $(0.186)$ & $(0.156)$ \\
\hline \multirow[t]{3}{*}{ * Large bank } & $-0.099^{a}$ & $-0.374^{a}$ & $-0.013^{c}$ & 0.406 & 0.325 \\
\hline & $(0.029)$ & $(0.025)$ & $(0.007)$ & $(0.289)$ & $(0.286)$ \\
\hline & {$[0.0018]^{a}$} & {$[0.00]^{a}$} & {$[0.21]$} & {$[0.015]^{b}$} & {$[0.068]^{c}$} \\
\hline$\Delta$ borrowing & $144.135^{a}$ & $17.096^{b}$ & $24.354^{a}$ & $76.697^{* *}$ & $19.783^{*}$ \\
\hline$\Delta$ lending & $-1.638^{c}$ & $42.037^{b}$ & 0.358 & 2.385 & 75.622 \\
\hline Trend & $-0.003^{a}$ & $-0.011^{a}$ & $-0.001^{a}$ & $-0.022^{a}$ & $0.018^{a}$ \\
\hline I(Large bank) & $0.120^{a}$ & $0.374^{a}$ & $0.015^{a}$ & $0.182^{a}$ & $0.920^{a}$ \\
\hline Observations & 123145 & 123145 & 123145 & 5326 & 15732 \\
\hline Banks & 7526 & 7526 & 7526 & 1783 & 3421 \\
\hline Countries & 72 & 72 & 72 & 72 & 68 \\
\hline Adjusted $R^{2}$ & 0.156 & 0.193 & 0.018 & $\alpha: 0.73^{a}$ & $0.47^{a}$ \\
\hline
\end{tabular}

Linear probability regressions in columns (1)-(3). Negative binomial (NB) regressions in columns (4) and (5). Dispersion parameter in NB regressions is $1+\alpha e^{X^{\prime} \beta}$, where $\alpha$ is estimated. $\alpha=0$ corresponds to Poisson regression. NB estimated by ML. Large bank is Large borrower in columns (1) and (4), large lender in columns (2) and (5), large lender and borrower in column (3). Country fixed effects included in all regressions. Robust standard errors clustered on country in parenthesis. P-vales of Wald test in (1)-(3) and $\chi^{2}$ test in (4)-(5) of joint significance of the main effect and the interaction term in square brackets.

${ }^{a}$ significant at $1 \%$ level; ${ }^{b}$ significant at $5 \%$ level; ${ }^{c}$ significant at $10 \%$ level. 